\title{
A possibility of saving an endangered endemic of the Lake Baikal shore, Hedysarum zundukii Peschkova (Fabaceae Lindl.) using clonal micropropagation
}

\author{
Kim Z. Gamburg \\ Siberian Institute of Plant Physiology and Biochemistry, Siberian Branch of the Russian Academy of Sciences, Irkutsk, Russia; \\ gamburg@sifibr.irk.ru \\ Received 22 October 2013; revised 22 November 2013; accepted 29 November 2013 \\ Copyright (C) $2013 \mathrm{Kim}$ Z. Gamburg. This is an open access article distributed under the Creative Commons Attribution License, \\ which permits unrestricted use, distribution, and reproduction in any medium, provided the original work is properly cited. In accor- \\ dance of the Creative Commons Attribution License all Copyrights (C) 2013 are reserved for SCIRP and the owner of the intellectual \\ property Kim Z. Gamburg. All Copyright (C) 2013 are guarded by law and by SCIRP as a guardian.
}

\section{ABSTRACT}

Hedysarum zundukii Peschkova is one of the Fabaceae endemics of the flora of the Lake Baikal west shore. Because of its very poor renewal by seed production and seedling appearance biotechnological method, clonal micropropagation has been elaborated in order to improve its chances of conservation. A protocol for clonal micropropagation, including introduction, propagation, rooting, acclimatization, field cultivation and prolonged cold storage has been elaborated. Half-dose MS salts, benzylaminopurine $1 \mathrm{mg} / \mathrm{dm}^{3}$ and $2 \%$ sucrose were optimal components of the medium for clonal micropropagation. Sucrose was the superior carbon source by comparison with glucose and maltose. It was found that some agar brands were better for propagation, whereas other ones were better for rooting. Transplants produced from acclimatized plantlets vegetated successfully in field conditions, but did not survived in Irkutsk after wintering. However, the same transplants planted into their natural population survived successfully. Micropropagated plantlets retained their ability for propagation in vitro after 10 - 12 months of cold storage at $4^{\circ} \mathrm{C}$ with illumination. It was concluded that clonal micropropagation may be used as an additional means for conservation of H. zundukii.

Keywords: Agar Brands; Carbon Sources; Clonal Micropropagation; Cold Storage; Conservation of Rare Plant Species; Hedysarum Zundukii Peschkova

\section{INTRODUCTION}

Hedysarum zundukii Peschkova (HZ) is one of many endemics of Fabaceae Lindl. family of the flora of the Lake Baikal west shore [1,2]. It is listed in the Irkutsk Regional Red Book [3] and Russian Federal Red Book [4]. Its existence is under increasing danger of extinction. HZ grows only along an $18 \mathrm{~km}$ stretch of the west shore of the Lake Baikal near the Island of Olkhon (in the Pribaikal National Park) [1,2]. The main part of its range covers an area $8 \mathrm{~km}$ long and $0.5 \mathrm{~km}$ wide [5]. $\mathrm{HZ}$ is a relict of ancient pre-glacial desert-steppe flora. It is an obligate calciphil and grows as single specimens in a mixed-grass petrophyt steppes on steep carbonate slopes and their stony sleeves and strews [6].

The general duration of $\mathrm{HZ}$ ontogenesis amounts to nearly 80 years. The generative period begins at 20 years and lasts to the age of $50-70$ years. Seed productivity is very low [6]. Seed propagation does not occur each year, and shoots appear only in years with favorable moisture. Periods suitable for germination are short and seedlings are practically absent in dry years. Even in favorable years few shoots appear.

The study of the ontogenetic structure of HZ cenopopulations revealed that they are characterized by low density and prevalence of old plants. This is the main reason for the rare occurrence of $\mathrm{HZ}$ and requires measures for the preservation of its natural habitat sites, elaboration of methods for its propagation, restoration of natural populations and creation of new ones [7]. Reintroduction of $\mathrm{HZ}$ by seed sowing is possible, but low seed productivity and weak seedling survival make this way of propagation problematic.

The possibility of using clonal micropropagation (CMP) for preservation of rare plant species attracts the attention of investigators because it has some advantages: high 
propagation quotient, propagation of plants recalcitrant to usual ways of propagation, year round propagation and others [8-10]. There are examples of successful reintroduction of rare endangered plants cultured in vitro into sites of their natural occurrence [11-15]. CMP is especially necessary for plants which do not produce seeds or have a very low rate of their production. HZ is a plant of this type. HZ has serious problems with renewal of populations by seed production, germination and seedling surviving $[5,6]$. It is supposed that CMP may be used for rapid production of great number of transplants for reintroduction from small number of seeds. In vitro plantlets can be used also for prolonged conservation of this species in addition to storage in seed bank. The aim of this work was to elaborate CMP of $\mathrm{HZ}$ in order to include it into a system of measures directed towards conservation of this plant species.

\section{MATERIALS AND METHODS}

HZ bean segments were gathered in 2008 and 2009 mainly at the Cape Zunduk and the river of the same name on the west shore of Lake Baikal in Pribaikal National Park. 19 intact mature seeds of the mean weight were scarified on thin file and exposed for 1 minute in $70 \%$ ethanol then for 15 minutes in $1 \%$ solution of $\mathrm{NaOCl}$ with added Twin-20 and washed three times for 5 min. each in sterilized water. After that, they were placed into plastic containers (volume $30 \mathrm{ml}$ "Sarstedt", Germany) with $10 \mathrm{ml}$ of medium H1 (Table 1) for germination. Germination was performed in darkness at $23^{\circ} \mathrm{C}$. Seedlings were transferred to a growing room at $23^{\circ} \mathrm{C}$ and illumination with fluorescent lamps $16 \mathrm{~h}$ per day when cotyledons were unfolded. The upper parts of the seedlings with cotyledons, true leaves and upper parts of hypocotyls were cut off after the appearance of $1-2$ true leaves and placed into the plastic containers with $10 \mathrm{ml}$ of the medium H2 (Table 1) for propagation. The remaining parts of hypocotyls were cut into $5-\mathrm{mm}$ segments and put on the medium H3 (Table 1) for induction of regenerants.

Propagation of axillary and adventive regenerants was performed with the use of the medium H2 (Table 1). The shoots were cultivated on the rooting medium H4 (Table 1) for root induction. Long-term storage of cultures was accomplished at $4^{\circ} \mathrm{C} \pm 2{ }^{\circ} \mathrm{C}$. Media compositions used in this study are shown in Table 1. MS salts M5524, vitamins, BAP, IBA, NAA, TDZ and phytagel were from "Sigma-Aldrich" (USA-Germany), saccharose from "Helicon" (Moskow State University, Russia), agar from different suppliers and DEDTC of Russian production as an antioxidant.

Baby food jars (volume $200 \mathrm{ml}$ ) with Magenta B-caps ("Sigma-Aldrich") with $25-30 \mathrm{ml}$ of media and $5-7$ explants in each of them were used for cultivation of established cultures. Each experimental variant contained 3 - 5 jars, experiments were repeated at least twice and the results were qualitatively similar. For cold storage, the explants were placed into glass flasks with $20 \mathrm{ml}$ of H6 medium (Table 1), closed with filter paper and aluminum foil and transferred into the refrigerator at $4^{\circ} \mathrm{C} \pm 2^{\circ} \mathrm{C}$ and continuous illumination with 2 fluorescent $40 \mathrm{w}$ lamps for prolonged cultivation. Statistical errors were estimated with the use of Microsoft Excel Program by formula:

$$
S E=\sqrt{\frac{\sum(x-X)^{2}}{n(n-1)}}
$$

where $S E$ is standard error, $x$ is measurement, $X$ is arithmetic mean of $n$ measurements. Arithmetic means and their standard errors are indicated in tables.

Rooted explants were planted into plastic containers

Table 1. Media for the in vitro culture of Hedysarum zundukii Peschkova.

\begin{tabular}{|c|c|c|c|c|c|c|}
\hline \multirow{2}{*}{$\begin{array}{c}\text { Components, } \\
\mathrm{mg} / \mathrm{dm}^{3}\end{array}$} & $\begin{array}{c}\text { Seed } \\
\text { germination }\end{array}$ & Introduction & $\begin{array}{c}\text { Induction } \\
\text { of regenerants }\end{array}$ & Propagation & Rooting & Cold storage \\
\hline & H1 & $\mathrm{H} 2$ & $\mathrm{H} 3$ & $\mathrm{H} 4$ & H5 & H6 \\
\hline Salts & \multicolumn{6}{|c|}{$1 / 2 \mathrm{MS}$} \\
\hline Thiamine- $\mathrm{HCl}$ & 0 & \multicolumn{5}{|c|}{1} \\
\hline Pyridoxine- $\mathrm{HCl}$ & 0 & \multicolumn{5}{|c|}{0.5} \\
\hline Nicotinic acid & 0 & \multicolumn{5}{|c|}{0.5} \\
\hline BAP & 0 & 1 & 0.5 & 1 & 0 & \pm 1 \\
\hline IBA & 0 & 0.1 & 0 & 0 & 1 & 0.1 \\
\hline NAA & 0 & 0 & 02 & 0 & 0.1 & 0 \\
\hline Na-DEDTK & \multicolumn{6}{|c|}{5} \\
\hline Saccharose & 10,000 & \multicolumn{5}{|c|}{20,000} \\
\hline Agar & \multicolumn{6}{|c|}{$7000-8000$} \\
\hline TDZ & 0 & 0 & 0.25 & 0 & 0 & 0 \\
\hline
\end{tabular}

MS—Salts of Murashige and Skoog [16] medium. 
(volume $200 \mathrm{ml}$ ) with marketed peat soil ("Fart", SanktPetersburg, Russian Federation) containing $\mathrm{NH}_{4}+\mathrm{NO}_{3}$ $150 \mathrm{mg} / \mathrm{dm}^{3}, \mathrm{P}_{2} \mathrm{O}_{5} 270 \mathrm{mg} / \mathrm{dm}^{3}, \mathrm{~K}_{2} \mathrm{O} 300 \mathrm{mg} / \mathrm{dm}^{3}$, with the addition of $25 \%$ vermiculite. The soil was heated in a microwave oven for $7 \mathrm{~min}$ for partial sterilization. Containers with plants were cultivated for the first 10 days in a growing room at $23^{\circ} \mathrm{C}$ and illuminated with fluorescent lamps $16 \mathrm{~h}$ per day. They were covered with transparent plastic film in order to decrease excessive transpiration. After that, they were transferred to a greenhouse with natural illumination and unregulated temperature. They were planted into the experimental field plot of the institute in mid-May and into the natural habitat in mid-June.

\section{RESULTS}

Induction of CMP. All 19 used seeds swelled signifying that scarification was successful. However, only 7 seeds produced normal seedlings suitable for CMP induction. Hypocotyls cuttings from these seeds produced significant numbers of regenerants, but most of them were vitrificated. A high concentration of cytokinin is one of factors responsible for vitrification [17]. In order to get rid of it, alternation of cultivation on the media with and without BAP $1 \mathrm{mg} / \mathrm{dm}^{3}$ was used and only normal regenerants were selected for the next subculture period of propagation. However, this procedure was not efficient for one of the 7 seeds used for introduction. All regenerants of this seed remained vitrificated and dead after three subcultures. In order to minimize the possibility of somaclonal deviations, we tried also to initiate propagation from the apical parts of seedlings. They did not begin propagation for a long time and a significant number of vitrificated regenerants appeared on their bases. They were removed constantly. Shoot growth from apical and axillary meristems began after some time. As a result, several clones were obtained from preexistent and adventive meristems.

Propagation. Each regenerant planted on the fresh medium formed a "bushlet" consisting of several rosettes connected to the general caudex (Figure 1) and can be easily separated from it. The separated parts were named "particulates". The particulate contained from 1 to 5 rosettes in close association. The "bushlet" grown after 6 8 week's subculture period was separated on particulates which were used as explants for the next subculture. The planted particulate was transformed to the new "bushlet" to the end of the subculture (Figure 2). The number of particulates in the "bushlet" was considered as a measure of propagation quotient.

It was observed that the intensive media browning occurred sometimes during cultivation. In order to diminish it, $5 \mathrm{mg} / \mathrm{dm}^{3}$ sodium DEDTC was included into all media as an antioxidant.

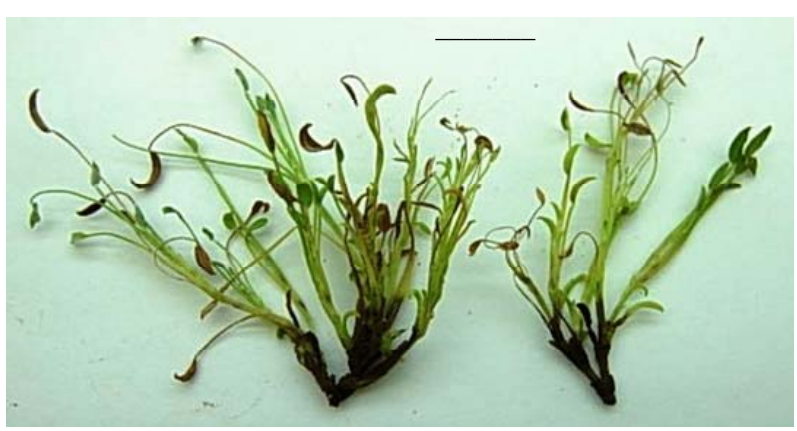

Figure 1. Particulates of $H$. zundukii at the end of subculture. Bar $1 \mathrm{~cm}$.

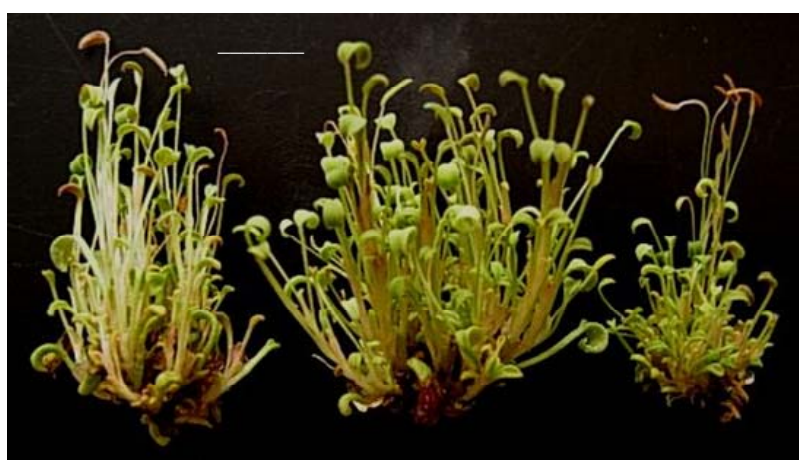

Figure 2. Each "bushlet" of H. zundukii was grown from one particulate. Bar $1 \mathrm{~cm}$.

The influence of different BAP concentrations. As shown in Table 2, an increase of BA concentration from 0.1 to $1 \mathrm{mg} / \mathrm{dm}^{3}$ caused an increase of PQ. Further increase of BAP concentration to $1.5 \mathrm{mg} / \mathrm{dm}^{3}$ did not stimulate the propagation further. The influence of BAP consisted also in the increase of rosette number in the particulate. Their numbers were least in the absence of BAP in the medium and it varied from 3.11 to 3.72 at 0.1 - $1.5 \mathrm{mg} / \mathrm{dm}^{3}$. It may be concluded that BAP concentration $1 \mathrm{mg} / \mathrm{dm}^{3}$ is optimal for $\mathrm{HZ}$ propagation, but fresh weight per one rosette was minimal at this concentration due to its shorter length.

The influence of sugars on HZ propagation. It was established that $\mathrm{HZ}$ propagation proceeded most intensively at $2 \%$ sucrose and to some extent more weakly at $1 \%$, $3 \%$ and $5 \%$ concentrations (Table 3). Glucose acted significantly more weakly at $1 \%$ and $2 \%$, but had the same as sucrose effect at 3\% and 5\%. Many small rosettes appeared at the base of explants at $5 \%$ of sucrose and glucose which were the reason for significant increase in the weight of grown explants (Figure 3). They were unsuitable for propagation and were not taken into account at the calculation of PQ. The results of the comparison of the effects of sucrose and maltose on $\mathrm{HZ}$ propagation are presented in Table 4. It may be seen that sucrose was a better sugar than maltose. It may be concluded that $2 \%$ sucrose was optimal for $\mathrm{HZ}$ propagation. 
Table 2. The effects of different BAP concentrations in $\mathrm{H} 4$ medium on the in vitro propagation of Hedysarum zundukii Peschkova.

\begin{tabular}{cccc}
\hline $\begin{array}{c}\mathrm{BAP}, \\
\mathrm{mg} / \mathrm{dm}^{3}\end{array}$ & PQ & $\begin{array}{c}\text { Mean number of } \\
\text { rosettes per 1 particulate }\end{array}$ & $\begin{array}{c}\text { Mean weight } \\
\text { of 1 rosette, mg }\end{array}$ \\
\hline 0 & $2.6 \pm 0.51^{*}$ & $1.69 \pm 0.21$ & $64.0 \pm 7.2$ \\
0.1 & $1.6 \pm 0.40$ & $3.50 \pm 1.13$ & $44.4 \pm 4.6$ \\
0.25 & $1.8 \pm 0.37$ & $3.11 \pm 0.54$ & $57.4 \pm 8.9$ \\
0.50 & $3.4 \pm 0.60$ & $3.12 \pm 0.49$ & $53.4 \pm 10.6$ \\
1.00 & $5.8 \pm 0.58$ & $3.72 \pm 0.32$ & $32.0 \pm 2.1$ \\
1.50 & $4.8 \pm 0.8$ & $3.13 \pm 0.35$ & $37.6 \pm 1.3$ \\
\hline
\end{tabular}

*SE, $\mathrm{n}=5$.

Table 3. Effects of different concentrations of sucrose and glucose in $\mathrm{H} 4$ medium on the in vitro propagation of Hedysarum zundukii Peschkova.

\begin{tabular}{|c|c|c|c|c|c|}
\hline \multirow{2}{*}{ Sugars } & \multirow{2}{*}{ Parameters } & \multicolumn{4}{|c|}{ Concentrations, $\%$} \\
\hline & & 1 & 2 & 3 & 5 \\
\hline \multirow[t]{2}{*}{ Sucrose } & $\begin{array}{l}\text { Mean weight } \\
\text { of grown } \\
\text { explant, mg }\end{array}$ & $515 \pm 90^{*}$ & $696 \pm 128$ & $543 \pm 48$ & $954 \pm 151$ \\
\hline & PQ & $4.00 \pm 0.44$ & $5.57 \pm 1.00$ & $4.50 \pm 0.38$ & $4.14 \pm 0.55$ \\
\hline \multirow[t]{2}{*}{ Glucose } & $\begin{array}{c}\text { Mean weight } \\
\text { of grown } \\
\text { explant, mg }\end{array}$ & $360 \pm 53$ & $555 \pm 91$ & $639 \pm 109$ & $938 \pm 117$ \\
\hline & $P Q$ & $2.71 \pm 0.18$ & $3.62 \pm 0.56$ & $4.75 \pm 0.67$ & $4.75 \pm 0.82$ \\
\hline
\end{tabular}

${ }^{*} \mathrm{SE}, \mathrm{n}=5$.

Table 4. Effects of $2 \%$ sucrose and $2 \%$ maltose in $\mathrm{H} 4$ medium on the in vitro propagation of Hedysarum zundukii Peschkova.

\begin{tabular}{ccc}
\hline Parameters & Sucrose & Maltose \\
\hline PQ & $8.0 \pm 0.75^{*}$ & $5.87 \pm 0.85$ \\
Mean number of rosettes per 1 particulate & $2.28 \pm 0.6$ & $1.87 \pm 0.18$ \\
Mean number of rosettes per 1 "bushlet" & $18.25 \pm 2.28$ & $11.0 \pm 1.31$ \\
Mean weight per 1 "bushlet", mg & $1103 \pm 145$ & $665 \pm 77$ \\
Mean weight per 1 rosette, mg & $60.4 \pm 3.38$ & $60.5 \pm 3.33$ \\
\hline
\end{tabular}

*SE, $\mathrm{n}=7$.

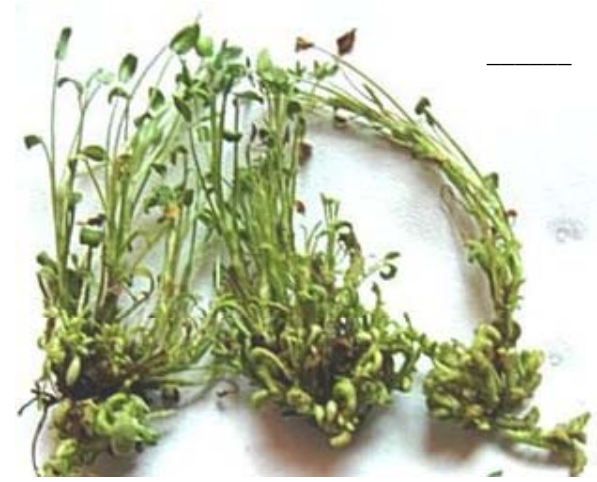

Figure 3. "Bushlets" of $H$. zundukii grown on the medium with $5 \%$ sucrose. Bar $1 \mathrm{~cm}$.
The dependence of $\mathrm{HZ}$ propagation from mineral composition of media. As postulated by Karnaukhova et al. [8] HZ is an obligate calciphyl. We proposed that the medium which contains more calcium than MS medium may be more favorable for $\mathrm{HZ}$ growth in vitro. The medium of Cañas and Benbadis [18] which contains 2 times more $\mathrm{Ca}, 4$ times more $\mathrm{Mg}, 2$ times more $\mathrm{P}, 2$ times less $\mathrm{NO}_{3}$ and 4 times less $\mathrm{NH}_{4}$ than MS medium was used for this purpose. Data presented in Table 5 shows that $1 / 2$ MS was optimal for $\mathrm{HZ}$ propagation and MS and 1/2 OM was little different from it. A full dose of OM salts caused intensive chlorosis and inhibited propagation.

The influence of agar of different brands and phytagel. We found that some agars induced severe inhibition of potato and vine CMP and rooting in vitro (data not shown). Therefore, it was decided to examine following gel-forming substances: phytagel (PG) and agar A-7002 (SA) of "Sigma-Aldrich" (USA-Germany), agar of the firm "Biomedicals" (BM) (Germany), agar (HC) supplied by "Helicon" (Moscow, Russian Federation) and agar (BT) supplied by "Biotechinnovatsiya" (Moscow, Russian Federation). As shown in Table 6, the largest PQ has been obtained in the presence of $\mathrm{HC}$ and $\mathrm{BM}$ agars and the least in the presence of SA agar and PG. The reverse was seen for particulate heights.

Induction of rooting. The particulates were transferred to rooting medium with IBA $1 \mathrm{mg} / \mathrm{dm}^{3}$ and NAA 0.1 $\mathrm{mg} / \mathrm{dm}^{3}$, whereas BAP was excluded (H5, Table 1). Medium with $1 / 2 \mathrm{MS}$ was better for rooting than the medium with $1 / 2 \mathrm{OM}$ salts (data not shown). As shown in Table 7, agar SA was the best for rooting while there

Table 5. Growth of on the in vitro culture of Hedysarum zundukii Peschkova. on H4 media with MS or OM (Cañas and Benbadis 1988) salts.

\begin{tabular}{|c|c|c|c|c|}
\hline Parameters & MS & $1 / 2 \mathrm{MS}$ & $1 / 2 \quad \mathrm{OM}$ & $\mathrm{OM}$ \\
\hline $\begin{array}{l}\text { Mean weight of } 1 \text { grown } \\
\text { explant, mg }\end{array}$ & $346 \pm 78^{*}$ & $530 \pm 58$ & $464 \pm 100$ & $139 \pm 30$ \\
\hline PQ & $3.1 \pm 0.5$ & $4.0 \pm 0.5$ & $3.2 \pm 0.4$ & $1.5 \pm 0.1$ \\
\hline
\end{tabular}

Table 6. Propagation of Hedysarum zundukii Peschkova. on $\mathrm{H} 4$ media with different gel-forming components ( $\mathrm{PG}$ - phytagel and SA - agar A-7002 of "Sigma-Aldrich", USA-Germany; BM - agar of the firm "Biomedicals", Germany; HC — agar supplied by "Helicon", Moscow, Russian Federation; BT-agar supplied by "Biotechinnovatsiya", Moscow, Russian Federation).

\begin{tabular}{cccccc}
\hline \multirow{2}{*}{ Parameters } & \multicolumn{5}{c}{ Gel-forming components } \\
\cline { 2 - 6 } & PG & HC & BM & BT & SA \\
\hline $\begin{array}{c}\text { Mean height of } \\
\text { particulate, cm }\end{array}$ & $3.9 \pm 0.4^{*}$ & $2.6 \pm 0.3$ & $2.6 \pm 0.1$ & $3.1 \pm 0.2$ & $4.0 \pm 0$ \\
PQ & $3.2 \pm 0.8$ & $5.0 \pm 1.2$ & $5.0 \pm 0.8$ & $4.0 \pm 1.0$ & $3.2 \pm 0.4$ \\
\hline
\end{tabular}

${ }^{*} \mathrm{SE}, \mathrm{n}=7$. 
were no roots on the medium with PG. It was observed that when some agars were used 5 years after their delivery they diminished or even lost their suitability for rooting (Table 7, Figure 4).

Acclimatization and growing in soil. $\mathrm{HZ}$ plantlets were extremely sensitive to fungal infection during the first days of acclimatization that led to the ruin of a significant number of them. As yet protection against fungal infection is an unresolved problem in $\mathrm{HZ}$ acclimatization. However, some number of plants remained alive and was planted into open field conditions on the experimental plot of the institute (Figure 5). The plants vegetated actively at summer after the transfer to field conditions, but most of them did not survive after winter in Irkutsk condition. Plants transferred into pots (diameter $20 \mathrm{~cm}$ ) and placed in autumn into greenhouse continued to vegetate during the winter with no signs of resting period (Figure 6). 26 transplants grown from rooted plantlets were planted into the depressed $\mathrm{HZ}$ population on the west shore of Lake Baikal with very few numbers of juvenile plants at June 2012. Examination at June 2013 revealed that plants had survived successfully.

Table 7. Rooting of of Hedysarum zundukii Peschkova. On H5 media with different gel-forming components (see Table 6 for abbreviations, fresh-agars obtained in 2010, old-agars obtained in 2005).

\begin{tabular}{cc}
\hline Types of agars & Rooted explants, $\%$ \\
\hline BM & $18.5 \pm 18.5^{*}$ \\
SA, fresh & $94.4 \pm 3.2$ \\
SA, old & $66.7 \pm 11.1$ \\
BT, fresh & $44.4 \pm 11.1$ \\
BT, old & 0 \\
HC & $48.1 \pm 19.6$ \\
PG & 0
\end{tabular}

${ }^{*} \mathrm{SE}, \mathrm{n}=20$.
1

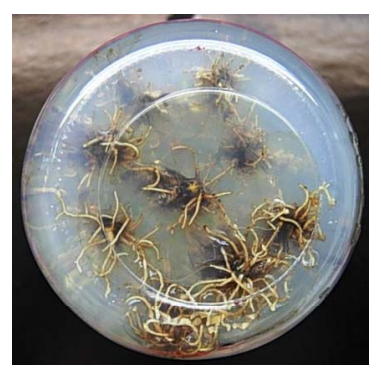

2

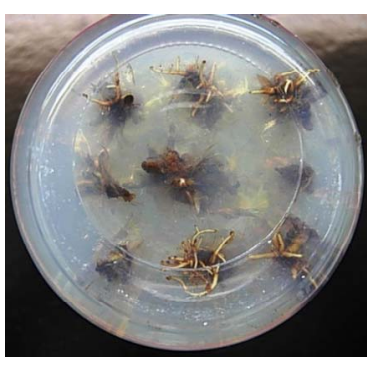

Figure 4. Rooting of $\mathrm{H}$. zundukii on medium with SA agar as it is seen from the bottom of jars. Agar obtained in: 1-2010, 22005. Bar $17 \mathrm{~mm}$.

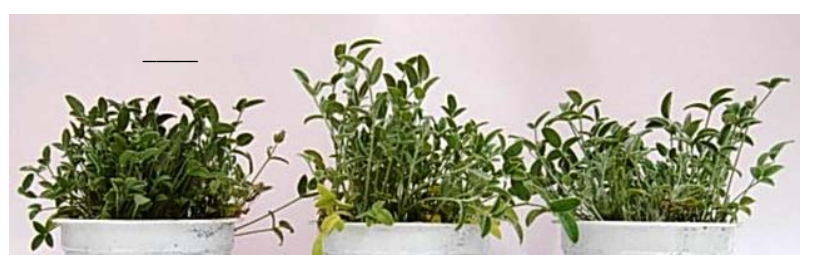

Figure 5. Transplant of $H$. zundukii grown in a greenhouse from in vitro plantlet. Bar $18 \mathrm{~mm}$.

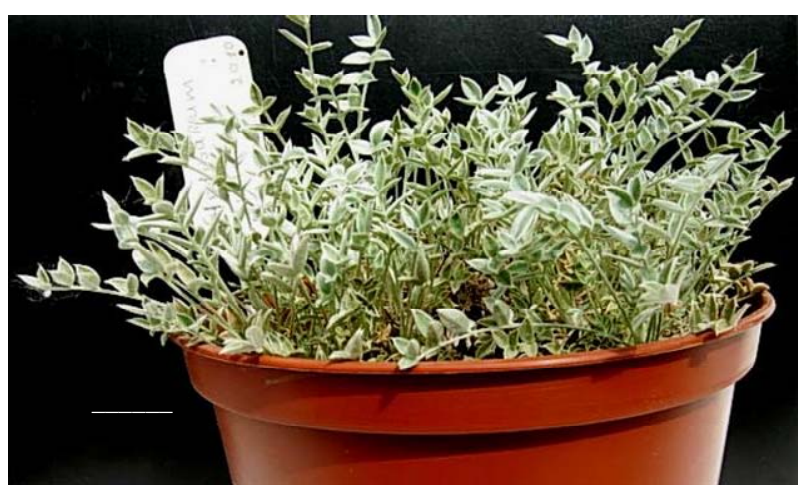

Figure 6. The plant of $H$. zundukii vegetated in a greenhouse for 1 year. Bar $21 \mathrm{~mm}$.

Prolonged conservation of HZ in isolated culture. Particulates were planted into cultural vessels with the H6 medium for cold conservation (Table 1) and cultured at $4^{\circ} \mathrm{C} \pm 2^{\circ} \mathrm{C}$. It was established that cultures lost viability in darkness after 3 - 4 months, whereas continuous illumination with low light intensity gave the possibility to keep cultures alive 12 or even more months independently of BA presence (Figure 7). Cultures returned into the growing room resumed growth after this period of the conservation and propagated when plantlets were transferred on fresh medium. As a result, a scheme of prolonged conservation in vitro of $\mathrm{HZ}$ clones was elaborated: 1) cultures grown on the propagation medium were planted on the medium for conservation and kept at $4^{\circ} \mathrm{C} \pm$ $2^{\circ} \mathrm{C}$ and low light $10-12$ months, 2) vessels with plantlets were transferred into the growing room with $23^{\circ} \mathrm{C}$ and illumination $16 \mathrm{~h}$ per day for 10 - 15 days, 3) explants which remained green and resumed growth were transferred on the medium for propagation and cultured 4 - 6 weeks, 4) grown explants were divided on particulates which were planted on the medium H6 for cold storage (Table 1) and this cycle of cultivation can be repeated. Using this scheme, we maintain our HZ cultures from 2009 to the present time.

\section{DISCUSSION}

The problem of intraspecies diversity conservation with CMP. Low seed productivity and difficulties with HZ seedling appearance in natural habitat [8] determinate the necessity of CMP for its conservation. As a rule, 


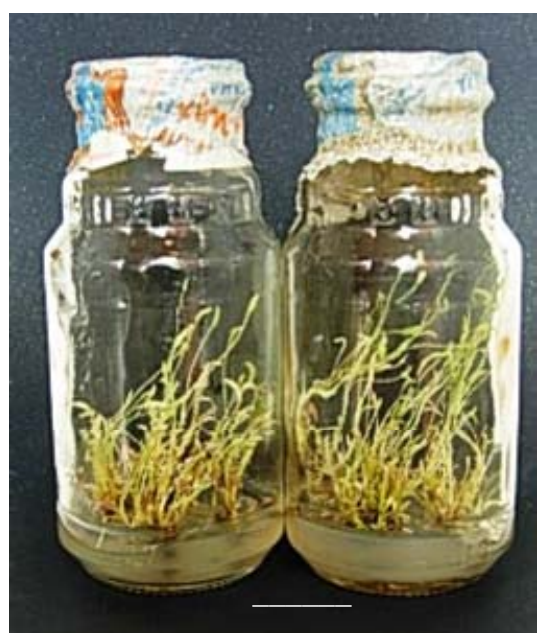

Figure 7. In vitro cultures of $H$. zundukii stored at $4^{\circ} \mathrm{C}$ for 1 year. Bar $2 \mathrm{~cm}$.

a limited number of exemplars (sometimes only one) are used for CMP initiation and for the introduction into botanical gardens. These exemplars cannot conserve all diversity of the species [19]. Seed banks are more efficient in this connection. A CMP obtained from different plants of the population and from different populations and maintenance of established cultures needs significant expenditure of labor and material resources. Therefore, the possibility of conservation of intraspecies diversity with CMP is very limited. In spite of that, we obtained clones from several seeds of $\mathrm{HZ}$ what can diversify to some extent its progeny in isolated culture.

It has been observed that there are differences in the success of disinfestations, the initiation and the rate of CMP between exemplars taken for CMP. Some exemplars are incapable of creating stabilized cultures and were excluded from the following in vitro culture. However, it is not known, if they would be able to survive in their natural inhabitats. CMP of HZ was initiated from only 7 seeds, whereas 19 seeds were used for introduction. It is possible that failure of the excluded seeds may be determined by their sensitivity to sterilization, media, temperature and illumination during introduction. Thus, the introduction into isolated culture itself can limit the possibility of CMP to conserve HZ biodiversity.

One of the problems of $\mathrm{HZ}$ introduction into CMP was strong vitrification of adventive regenerants caused by BAP presence in the medium. It is known that a decrease in cytokinin concentration or even its exclusion from the medium can diminish vitrification and normalize vitrificated regenerants [17]. However, BA was necessary for $\mathrm{HZ}$ propagation with an optimum at $1 \mathrm{mg} / \mathrm{dm}^{3}$ (Table 2). In order to remove the vitrification during introduction and propagation, we applied the alternation of subcultures on media with and without BA and only normal regenerants were used for each next subculture. In this way, it was possible to select regenerants which can remain normal in the presence of BA in the medium for propagation. It is not clear to what extent this selection is favorable for the subsequent survival of $\mathrm{HZ}$ in natural conditions.

$C M P$ as a means of $H Z$ conservation. CMP can be used to solve two tasks: 1) obtaining many plants suitable for field growing from limited number of seeds or vegetative plant parts, 2) prolonged conservation of rare endangered species by in vitro cultivation. Two ways of the introduction were tested: 1) activation of shoot propagation from axillary and apical meristems (separation of epicotyls and their cultivation with BA), 2) induction of the appearance of adventive regenerants (cultivation of hypocotyl sections with BA and TDZ). Thanks to the simultaneous use of these two ways, very great number of plants can be produced in short time. However, the danger of the appearance of the off-type plants from adventive regenerants is significantly greater than from axillary meristems [20]. It may be supposed that when it is necessary to produce a large number of plants for reintroduction in short time it is advisable to employ both ways of introduction. However, clones initiated from seedling apexes must be used for prolonged cold storage.

Carbon sources for CMP of HZ. There are many publications devoted to the choice of the best carbon source for plantlets regeneration in vitro and CMP. Sucrose was superior to maltose and glucose for CMP of potato [21], for regenerant appearance on hypocotyls of Sesbania rostrata [22] and for somatic embryogenesis in mung bean [23]. However, maltose was the best sugar for some plants [24-26]. Our attempts to improve CMP of HZ by substitution of sucrose by glucose or maltose gave no positive results.

Influence of agars of different brands and phytagel on $C M P$ of HZ. Some investigators found that agars of different sources caused different effects on in vitro cultures. Pochet et al. [27] found that Roth agar containing too much $\mathrm{SO}_{4}$ was the worst for CMP of Thuja plicata. This agar exerted also negative influence on CMP of Ranunculus asiaticus L., whereas Oxoid agar was better [28]. Shoots of the marubakaido apple rootstock had significantly lower multiplication rate in the media containing BBL agar compared to A-7002, A-7921, Select agars, and Phytagar as gelling agents [29]. We also found that some agars induced severe inhibition of potato and vine CMP (data not shown). We found that agar quality exerted significant influence on HZ propagation and rooting in vitro.

As shown in Table 6, the greatest PQ was observed on the medium with $\mathrm{HC}$ agar. However, this agar was unsuitable for CMP of potato and wines (our unpublished results) and was not optimal for HZ rooting (Table 7). On the other hand, SA agar was not optimal for HZ propagation, but it gave the best results when used for root- 
ing. So, different agars may be used for different processes included into CMP (introduction, propagation, rooting, and cold storage).

Acclimatization and field growing. It was established that HZ suffered from fungal infection and some number of plantlets were lost during acclimatization. Great sensitivity of $\mathrm{HZ}$ seedlings to fungi was indicated also in the communication [30]. The reason for this sensitivity may be that drought climate of $\mathrm{HZ}$ natural habitat is not conductive for fungal infestation. It is possible that some fungicides may help in resolving this problem. HZ transplants planted in field plot of our institute in Irkutsk vegetated successfully, but few of them survived the winter. The same was observed in the Central Botanical Garden in Novosibirsk where HZ plants grown from seeds did not survive also [31]. Probably, excessive dampness during snow thawing at spring is the main reason for the loss of plants in these two places. Successful survive of $\mathrm{HZ}$ planted into natural population confirms this supposition.

Long-term conservation of $H Z$. Cultivation in vitro may be considered not only as a mean for propagation, but also for conservation of endangered plant species in addition to seed banks and introduction into botanical gardens. One way of the in vitro conservation consists in the periodical transfers on fresh medium. HZ must be transferred every $6-8$ weeks, i.e. $6-8$ times per one year which needs significant expenditures of labor and material resources. Frequent transfers may cause an accumulation of undesirable genetic deviation and a loss of cultures owing to fungal and bacterial contaminations. Conservation at $-196^{\circ} \mathrm{C}$ [32] is complicated and needs continuous supply of liquid nitrogen.

Another method of prolonged conservation is the cultivation at low above zero temperatures what gives the possibility to increase subculture period to 12 or even more months. Luo et al. [33] compared cold storage at $4^{\circ}$ and cryopreservation of some hairy-root cultures and came to the conclusion than cold storage is the better way of conservation. Many other authors have applied low above-zero temperatures for conservation of in vitro cultures [34-36]. Cold storage at $4^{\circ}$ was also applied for $\mathrm{HZ}$ in this work. The possibility to storage of cultures for 12 - 13 months was demonstrated with successful growth resumption after this period. It was established that light with low intensity was necessary for this success. Romano and Martins-Loucão [36] found that cork oak needed darkness for prolonged storage at $5^{\circ} \mathrm{C}$. Potato conservation at $4^{\circ} \mathrm{C}$ was improved by light, whereas it was unnecessary for chokecherry and Saskatoon berry [37]. The longest period of cold storage (33 - 39 months) was communicated by Kovalcuk et al. [34] for apple microplants. However, cold storage period cannot be unlimited and must be interrupted with usual culture at $20^{\circ} \mathrm{C}-25^{\circ} \mathrm{C}$. A combination of cold storage at $4^{\circ} \mathrm{C}$ for $10-12$ months and one subculture period at $23^{\circ} \mathrm{C}$ was applied for $\mathrm{HZ}$ conservation in this work for 3 years (2009-2013) and will be applied further.

\section{CONCLUSIONS}

A protocol for CMP of HZ including introduction, propagation, rooting, acclimatization and reintroduction was elaborated. It can be supposed that renovation of $\mathrm{HZ}$ in vitro culture will be necessary after some years. The data obtained in this work will be useful for initiation of CMP in this case. These data may also be taken into account when it will be necessary to propagate other Hedysarum species in vitro.

Thus, CMP of HZ may be used as an additional tool in the system of measures for diminishing danger of its extinction. It can be used when the requirement of many plants for reintroduction and for prolonged preservation by cold storage will be aroused.

\section{ACKNOWLEDGEMENTS}

I am thankful to candidates of biol. sci. S. G. Kazanovskii and A. V. Verkhozina for gathering $\mathrm{HZ}$ seed and submitting them for this work, for their help in planting transplants into the natural habitat of $\mathrm{HZ}$ existence and for valuable discussion. I also thank L. V. Amelushchenko and N. V. Kusmin students of the Irkutsk State University L. V. for their participation. This work received partial financial support from the Russian Fund for Fundamental Researches, grant number 08-04-98049.

\section{REFERENCES}

[1] Malishev, L.I. and Peshkova, G.A. (1984) Peculiarities and genesis of siberia flora (predbaikalie and zabaikalie). Novosibirsk, 265.

[2] Peshkova, G.A. (1979) Fabaceae or Leguminosae family. Flora of central Siberia. Novosibirsk, 2, 585-639.

[3] Red Book of Irkutsk district (2010) Irkutsk. OOO "Time of wander", 480.

[4] Red Book of Russian Federation (plants and fungi) (2008) Moscow Company of scientific editions KMK, 855.

[5] Bardunov, L.V., Makriy, T.V., Kiseleva, A.A. and Kazanovskii, S.G. (2006) Peculiarities of flora and vegetation of Priolkhonie (west shore of the lake Baikal). Botanical Journal (Russia), 91, 23-33.

[6] Karnaukhova, N.A., Selutina, I.U., Kazanovskii, S.G. and Cherkasova, E.S. (2008) Ontogenesis and structure of cenopopulations of Hedyzarum zundukii (Fabaceae)-An endemic of west shore of the lake Baikal. Botanical Journal (Russia), 93, 744-755.

[7] Karnaukhova, N.A., Selutina, I.U. and Cherkasova E.S. (2006) Estimation of cenopopulation stability of near to Baikal endemics-Hedisarum zundukii Peschkova, Oxytropis triphylla (Pallas) and Oxytropis popoviana Peschkova. Biodiversity of Inner Asia, Ulan-Ude, 131-132. 
[8] Paunescu, A. (2009) Biotechnology for endangered plant conservation: A critical overview. Romanian Biotechnological Letters, 14, 4095-4103.

[9] Pence, V.L. (2010) The possibilities and challenges of in vitro methods for plant conservation. Kew Bulletin, 65, 539-547. http://dx.doi.org/10.1007/s12225-011-9245-4

[10] Reed, B.M., Sarasan, V., Kane, M., Bunn, E. and Pence, V.C. (2011) Biodiversity conservation and conservation biotechnology tools. In Vitro Cellular \& Developmental Biology-Plant, 47, 1-4. http://dx.doi.org/10.1007/s11627-010-9337-0

[11] Ramsay, M.M. and Stewart, J. (1998) Re-establishment of the lady's slipper (Cypripedium calceolus L.) in Britain. Botanical Journal of the Linnean Society, 126, 173-181.

[12] Malá, J. and Bylinský, V. (2004) Micropropagation of endangered species Daphne cneorum. Biologia Plantarum, 48, 633-636. http://dx.doi.org/10.1023/B:BIOP.0000047167.18592.f7

[13] Cassells, A.C., Walsh, C., Belin, M., Cambornac, M., Robin, J.R. and Lubrano, C. (1999) Establishment of a plantation from micropropagated Arnica chamissonis a pharmaceutical substitute for the endangered A. montana. Plant Cell, Tissue and Organ Culture, 56, 139-144. http://dx.doi.org/10.1023/A:1006224215503

[14] Decruse, S.W., Gangaprasad, A., Seeni, S. and Menon, V.S. (2003) Micropropagation and ecorestoration of Vanda spathulata, an exquisite orchid. Plant Cell Tissue, Organ Culture, 72, 199-202. http://dx.doi.org/10.1023/A:1022267009531

[15] Misic, D.M., Ghalawenji, N.A., Grubisic, D.V. and Konjevic, R.M. (2005) Micropropagation and reintroduction of Nepeta rtanjensis, an endemic and critically endangered perennial of Serbia. Phyton-Annales Rei Botanicae, 45, 9-20.

[16] Murashige, T. and Skoog, F. (1962) A revised medium for rapid growth and bioassays with tobacco tissue cultures. Physiologia Plantarum, 15, 473-497. http://dx.doi.org/10.1111/j.1399-3054.1962.tb08052.x

[17] Ziv, M. (1991) Vitrification: morphological and physiological disorders of in vitro plants. In: Debergh, P.C. and Zimmerman, R.H., Eds., Micropropagation. Technology and Application, Kluwer Academic Publishers, Dordrecht, 45-69. http://dx.doi.org/10.1007/978-94-009-2075-0_4

[18] Cañas, L.A. and Benbadis, A. (1988) In vitro plant regeneration from cotyledon fragments of the olive tree (Olea europea L.). Plant Science, 54, 65-74. http://dx.doi.org/10.1016/0168-9452(88)90056-8

[19] Kamelin, R.V. (1997) Biological diversity and introduction of plants. Rastitelnye Resursi (Russia), 33, 1-11.

[20] Debergh, P.C. and Read, P.E. (1991) Micropropagation. In: Debergh, P.C. and Zimmerman, R.H., Eds., Micropropagation. Technology and Application, Kluwer Academic Publishers, Dordrecht, 1-14.

[21] Ling, N.X.Y. and Leung, D.W.M. (2010) Influence of sugars and light on rhizosecretion of $\alpha$-glucosidase and acid phosphatase during micropropagation of potato. Plant Cell, Tissue and Organ Culture, 103, 279-283.

[22] Jha, A.K., Prakash, S., Jain, N., Nanda, K. and Gupta, S.C.
(2002) Production of adventitious shoots and plantlets from the hypocotyl explants of Sesbania rostrata (Bremek \& Obrem). In Vitro Cellular \& Developmental Biology_Plant, 38, 430-434.

http://dx.doi.org/10.1079/IVP2002313

[23] Muruganantham, M., Amutha, S. and Ganapathi, A. (2010) Somatic embryo productions by liquid shake culture of embryogenic calluses in Vigna mungo (L.) Hepper. In Vitro Cellular \& Developmental Biology-Plant, 46, 34-40. http://dx.doi.org/10.1007/s11627-009-9224-8

[24] Zhang, C.-L., Chen, D.-F., Kubalakova, M., Zhang, J., et al. (2008) Efficient somatic embryogenesis in sugar beet (Beta vulgaris L.) breeding lines. Plant Cell, Tissue and Organ Culture, 93, 209-222. http://dx.doi.org/10.1007/s11240-008-9364-2

[25] Mendoza, M.G. and Kaeppler, H.F. (2002) Auxin and sugar effects on callus induction and plant regeneration frequencies from mature embryos of wheat (Triticum aestivum L.). In Vitro Cellular \& Developmental BiologyPlant, 38, 39-45. http://dx.doi.org/10.1079/IVP2001250

[26] Sairam, R.V., Franklin, G., Hassel, R., Smith, B., et al. (2003) A study on the effect of genotypes, plant growth regulators and sugars in promoting plant regeneration via organogenesis from soybean cotyledonary nodal callus. Plant Cell, Tissue and Organ Culture, 75, 79-85. http://dx.doi.org/10.1023/A:1024649122748

[27] Pochet, B., Scoman, V., Mestdagh, M.M., Moreau, B. and Andre, P. (1991) Influence of agar gel properties on the in vitro propagation of different clones of Thuja plicata. Plant Cell Reports, 10, 406-409. http://dx.doi.org/10.1007/BF00232612

[28] Beruto, M., Curir, P. and Debergh, P. (1999) Influence of agar on in vitro cultures: II. Biological performance of ranunculus on media solidified with three different agar brands. In Vitro Cellular \& Developmental BiologyPlant, 35, 94-101. http://dx.doi.org/10.1007/s11627-999-0017-x

[29] Pereira-Netto, A.B., Petkowicz, C.L.O., Cruz-Silva, C.T.A., Gazzoni, M.T., Mello, A.F.P. and Silveira, J.L.M. (2007) Differential performance of marubakaido apple rootstock shoots grown in culture media containing different agar brands: Dynamic rheological analysis. In Vitro Cellular \& Developmental Biology-Plant, 43, 356-363.

[30] Kilina, Y.G. and Zhmud, E.V. (2007) Trypsin-inhibiting activity and seed germination of some species of Fabaceae family and determination of their infection with fungi and bacteria microflora. Perspectives of Development and Problems of Contemporary Botanics, Novosibirsk, SO RAN, 327-329.

[31] Semenova, G.P. (2007) Rare and endangered species of siberian flora: Biology, conservation. "Geo" Academic Publishing. Novosibirsk, 408.

[32] Withers, L.A. (1985) Cryopreservation and storage of genofond. In: Dixon, R.A., Ed., Plant Cell Culture a Practical Approach, IRL Press (Russian translation, 1989, Agropromisdat), Moscow, 204-233.

[33] Luo, X.-J., Wu, Z.-H., Xue, S.-H., Zhang, H.-L. and Wang, X.-Y. (2008) Cold storage and cryopreservation of hairy root cultures of medicinal plant Eruca sativa Mill, As- 
tragalus membranaceus and Gentiana macrophylla Pall. Plant Cell, Tissue and Organ Culture, 92, 251-260. http://dx.doi.org/10.1007/s11240-007-9329-x

[34] Kovalchuk, I., Lyudvikova, Y., Volgina, M. and Reed, B.M. (2009) Medium, container and genotype all influence in vitro cold storage of apple germplasm. Plant Cell, Tissue and Organ Culture, 96, 127-136. http://dx.doi.org/10.1007/s11240-008-9468-8

[35] Sarkar, D., Chakrabarti, S.K. and Naik, P.S. (2001) Slowgrowth conservation of potato microplants: Efficacy of ancymidol for long-term storage in vitro. Euphytica, 117,

\section{ABBREVIATIONS}

$\mathrm{CMP}$ - clonal micropropagation

BAP- $\mathrm{N}^{6}$-benzylaminopurin

DEDTC - Na-diethyldithiocarbamate

HZ-Hedysarum zundukii
133-142. http://dx.doi.org/10.1023/A:1004087422743

[36] Romano, A. and Martins-Loução, M.A. (1999) In vitro cold storage of cork oak shoot cultures. Plant Cell, Tissue and Organ Culture, 59, 155-157.

http://dx.doi.org/10.1023/A:1006465706905

[37] Pruski, K., Kozai, T., Lewis, T., Astatkie, T. and Nowak, J. (2000) Sucrose and light effects on in vitro cultures of potato, chokecherry and saskatoon berry during low temperature storage. Plant Cell, Tissue and Organ Culture, 63, 215-221. http://dx.doi.org/10.1023/A:1010649725527

IBA-3-indole-3-butyric acid

MS-Murashige and Skoog [16] medium

NAA -1-naphthalene acetic acid

PQ_propagation quotient

TDZ-thidiazuron 